\title{
Experimental vertical transmission of Piscirickettsia salmonis and in vitro study of attachment and mode of entrance into the fish ovum
}

\author{
J. J. Larenas ${ }^{1, *}$, J. Bartholomew ${ }^{2}$, O. Troncoso ${ }^{1}$, S. Fernández ${ }^{1}$, H. Ledezma ${ }^{1}$, \\ N. Sandoval ${ }^{1}$, P. Vera ${ }^{1}$, J. Contreras ${ }^{1}$, P. Smith ${ }^{1}$ \\ ${ }^{1}$ Departamento de Patología Animal, Facultad de Ciencias Veterinarias, Universidad de Chile, Casilla 2 Correo 15, Chile \\ ${ }^{2}$ Department of Microbiology, Oregon State University, Corvallis, Oregon 97331, USA
}

\begin{abstract}
Piscirickettsia salmonis is a pathogenic bacterial agent causing septicaemic disease in salmon. Since its isolation in Chile in 1989, $P$. salmonis has continually produced high mortality rates in salmon farms. Little information exists regarding the mechanisms of vertical transmission of this pathogen. Experimental vertical transmission was established in the present study by inoculation of male and female rainbow trout broodstock with $P$. salmonis. The bacterium was subsequently detected using indirect immunofluorescence in milt and coelomic fluid of the majority of inoculated broodstock (14/15). Bacteria were detected in the fry when 1 or both parents were inoculated, although none of the infected fry presented signs of the disease. P. salmonis was also detected in progeny obtained through fertilisation ova from non-inoculated females incubated in a medium containing a bacterial suspension, demonstrating transmission during the process of fertilisation. Ova infected in vitro were examined at sample periods from $30 \mathrm{~s}$ to 60 min using scanning electron microscopy. This demonstrated that the bacterium attaches to the ova by means of membrane extensions, structures which we have called 'piscirickettsial attachment complex' (PAC) and which would allow later penetration into the ovum.
\end{abstract}

KEY WORDS: Bacteria $\cdot$ Piscirickettsia salmonis $\cdot$ Piscirickettsiosis $\cdot$ Vertical transmission $\cdot$ Scanning electron microscopy V Virulence factor

Resale or republication not permitted without written consent of the publisher

\section{INTRODUCTION}

Piscirickettsiosis is a septicaemic disease that has been reported from seawater salmon farms around the world (Fryer et al. 1990, Cvitanich et al. 1991, Grant et al. 1996, Olsen et al. 1997, Palmer et al. 1997, Jones et al. 1998). In Chile, the disease has caused serious economic losses due to high mortality rates and the elevated cost of treatment. It is caused by the bacterium Piscirickettsia salmonis (Fryer et al. 1992), which was first isolated in 1989 (Fryer et al. 1990).

Mechanisms for the transmission of Piscirickettsia salmonis are not well established. Smith et al. (1999) demonstrated experimental penetration of the bacterium through macroscopically intact skin and gills, producing mortality as well as macroscopic and histopathological lesions. Nonetheless, the mode of entry of $P$. salmonis through these routes is not known. In reference to the vertical transmission of the agent, Larenas et al. (1996b) demonstrated that P. salmonis can be transmitted experimentally from either male or female rainbow trout Oncorhynchus mykiss broodstock to their progeny. The agent was detected in 'eye stage' ova, but the persistence of the bacterium to later stages of development was not established. As $P$. salmonis was observed in large numbers in both coelomic and seminal fluids, we postulated that it would penetrate the ova during fertilisation. That hypothesis was tested in this study by experimentally infecting rainbow trout broodstock and examining the progeny of these fish as they progressed from ova to fry and alevin stages. 


\section{MATERIALS AND METHODS}

Fish. Rainbow trout Oncorhynchus mykiss broodstock (ca. $2000 \mathrm{~g})(\mathrm{n}=30$ ) were obtained from a fish farm located in an area where piscirickettsiosis has never been described (Fifth Region, Chile). Five fish from the farm were sampled to determine the initial infection status of the group. These fish were euthanized by anaesthetic overdose (benzocaina, Veterquímica) to perform necropsies, during which renal tissue-smears were evaluated using indirect immunofluorescence techniques (IFAT) to detect Renibacterium salmoninarum (BKD-Fluoro Test, BiosChile) and Piscirickettsia salmonis, the latter according to a method described by Lannan et al. (1991) and modified by Larenas et al. (1996a). Samples for bacteriology and virology were also obtained using standard techniques. AntiP. salmonis antibodies were kindly provided by Dr. John Fryer of Oregon State University, USA. The remaining fish were maintained in 2500 l plastic tanks in an experimental unit belonging to the Departamento de Patología Animal of the Facultad de Ciencias Veterinarias y Pecuarias, University of Chile (Santiago). Filtered and chlorine-free potable water flowed constantly into the tanks $\left(1 \mathrm{l} \mathrm{min}^{-1}\right)$. Outflow of water was chlorinated (5 ppm) and treated with UV light. Each tank was continuously supplied with air using a system of independent pumps (ca. $8 \mathrm{mg}^{-1}$ ). The fish were fed a commercially available pelleted food twice daily.

Piscirickettsia salmonis. Strain LF-89 (ATCC [R] VR 1361) (Fryer et al. 1992) was used to inoculate all experimental animals and ova. The bacteria was maintained and multiplied in the cell line CHSE-214 (ATCC CRL 1681) without antibiotics (Lannan et al. 1984), according to the methodology established by Fryer et al. (1990). The microorganism was utilised once a cytopathic effect close to $100 \%$ was observed. The supernatant was titered by endpoint dilution on microplates. Final titers were calculated using the technique of Reed \& Muench (1938).

Experimental design. Eight males and 7 females were inoculated intraperitoneally (IP) with $0.2 \mathrm{ml}$ of a suspension containing $10^{5.5} \mathrm{TCID}_{50} \mathrm{ml}^{-1}$ of Piscirickettsia salmonis Strain LF-89. Another group of 5 males and 5 females were not inoculated to obtain gametes free of P. salmonis. Gametes were collected for in vitro fertilisation by manual stripping at approximately $60 \mathrm{~d}$ post-inoculation (PI). After spawning the fish were euthanized for detection of $P$. salmonis.

Ova from all inoculated females $(\mathrm{F}+)$ were combined in a plastic container to create a gamete pool. Ova from non-inoculated females ( $\mathrm{F}-$ ), and milt from both inoculated and non-inoculated males $(\mathrm{M}+$ and $\mathrm{M}-$ ) were pooled in the same way. Each gamete pool was divided into equal parts to carry out cross fertilisation (Table 1).
Table 1. Piscirickettsia salmonis infecting Oncorhynchus mykiss. Experimental groups of fertile ova obtained from rainbow trout broodstock inoculated with $P$. salmonis (+) and from non-inoculated adults (-).

\begin{tabular}{|c|c|c|}
\hline \multirow[t]{2}{*}{ Ova group $^{a}$} & \multicolumn{2}{|c|}{ Brooder } \\
\hline & Male (M) & Female (F) \\
\hline $\mathrm{M}-\mathrm{F}-$ & $(-)$ & $(-)$ \\
\hline $\mathrm{M}+\mathrm{F}-$ & $(+)$ & $(-)$ \\
\hline $\mathrm{M}-\mathrm{F}+$ & $(-)$ & $(+)$ \\
\hline $\mathrm{M}+\mathrm{F}+$ & $(+)$ & $(+)$ \\
\hline $\mathrm{M}-\mathrm{F}-(+)^{\mathrm{b}}$ & $(-)$ & $(-)$ \\
\hline \multicolumn{3}{|c|}{$\begin{array}{l}{ }^{\mathrm{a}} \text { Fertilisation was carried out at approximately } 60 \mathrm{~d} \text { after } \\
\text { intraperitoneal inoculation of } P \text {. salmonis } \\
{ }^{\mathrm{b}} \text { This group of ova was obtained by experimental inocula- } \\
\text { tion of } P \text {. salmonis during fertilisation. } 30 \mathrm{ml} \text { of a suspen- } \\
\text { sion of } P \text {. salmonis with a titer of } 10^{6.2} \mathrm{TCID}_{50} \mathrm{ml}^{-1} \text { were } \\
\text { added to a group of } 600 \text { ova }\end{array}$} \\
\hline
\end{tabular}

Ova were artificially fertilised by the dry method, in which ova were mixed with milt and allowed to rest for a period of 15 min before placing them in an incubator tray with running water.

A third group of ova from the pool of F- broodstock was fertilised with milt from the M- pool. Immediately after the mixing, $30 \mathrm{ml}$ of a cell culture suspension of Piscirickettsia salmonis $\left(10^{6.2} \mathrm{TCID}_{50} \mathrm{ml}^{-1}\right)$ were added to the mixture and incubated for $15 \mathrm{~min}(\mathrm{M}-\mathrm{F}-[+])$. These crosses created 5 different groups of fertilised ova (Table 1). The 5 groups were incubated separately on mesh baskets in 1501 rectangular plastic tanks, supplied with air and a continuous and independent flow of water at $9^{\circ} \mathrm{C}$ and a rate of $11 \mathrm{~min}^{-1} \operatorname{tank}^{-1}$.

Detection of Piscirickettsia salmonis in adults. Adult fish were euthanized and the following samples were taken: renal tissue and coelomic and seminal fluids. Smears of tissue and fluids were evaluated using IFAT to detect Renibacterium salmoninarum and P. salmonis. Samples for bacteriology and virology were also obtained using standard techniques.

Detection of Piscirickettsia salmonis in fry. After incubating until hatching at 321 Accumulated Thermic Units, 25 sac fry (ca. $0.1 \mathrm{~g}$ ) were selected randomly from each group and processed individually. Each was euthanized with benzocaine and then ground, filtered (5 $\mu \mathrm{m}$ Millipore filter) and centrifuged. Two smears were obtained from each resulting pellet, and were fixed with methanol for $3 \mathrm{~min}$. Another sample of 25 fry was taken from each group when they reached an approximate weight of $1 \mathrm{~g}$, from which renal tissue smears were obtained. All samples obtained were analysed using immunofluorescent techniques as previously described.

Detection of Piscirickettsia salmonis in ova. Ova were obtained from a female not inoculated with $P$. 
salmonis. Two ova were placed in a $2.5 \mathrm{ml}$ Eppendorf tube containing $200 \mu \mathrm{l}$ of a suspension of $P$. salmonis $\left(10^{5.2} \mathrm{TCID}_{50} \mathrm{ml}^{-1}\right)$ for $30 \mathrm{~s}$. The medium containing the agent was previously filtered through $5 \mu \mathrm{m}$ Millipore filters. This procedure was repeated for periods of $45 \mathrm{~s}$ and for 1, 5, 10, 30 and 60 min. Another sample of ova $(\mathrm{n}=2)$ was placed in the bacterial suspension with $300 \mu \mathrm{l}$ of milt from a non-inoculated male for the same periods described above. Immediately after incubation, all ova samples were fixed in $3 \%$ glutaraldehyde (Sigma) in $0.1 \mathrm{M}$ sodium cacodylate for $24 \mathrm{~h}$, dehydrated in acetone, dried to critical point, and covered with $20 \mathrm{~nm}$ of gold. Two ova were available for each time period studied: 1 intact ovum with chorion or external membrane, and 1 in which the external membrane was surgically excised immediately after fixation. All samples were done in duplicate.

The ova were examined under a Tesla 343 scanning electron microscope operated at $20 \mathrm{kV}$. The images obtained were analysed using an image processing software (WinTip, v. 3.1a). Ova from the same female but not incubated in the Piscirickettsia salmonis suspension were used as negative controls.

\section{RESULTS}

\section{Vertical transmission}

No mortality, clinical signs of disease, or macroscopic lesions of piscirickettsiosis were observed in either inoculated broodstock or non-inoculated controls. Piscirickettsia salmonis was detected from renal tissue smears in 6 of 8 males $(75 \%)$, and 6 of 7 females $(85.7 \%)$ by IFAT (Table 2$)$. In these same fish, milt smears were positive in 7 of 8 males $(87.5 \%)$, and smears from coelomic fluid were positive in all inoculated females (7/7).

In the 3 groups of fry created from crosses where 1 or more parents were inoculated, detection of Piscirickettsia salmonis varied from 16 to $24 \%$ (Table 3). The bacterium was also detected in $28 \%$ of the fry created by incubating gametes from negative parents with $P$. salmonis $(\mathrm{M}-\mathrm{F}-[+])$. When progeny of these crosses were tested later, when fry were approximately $1 \mathrm{~g}$, the percent of fish positive in each group ranged from 12 to $16 \%$ (Table 3 ).

\section{In vitro attachment study}

Scanning electron microscope images show that at $45 \mathrm{~s}$ after initial contact of ova with the bacteria, Piscirickettsia salmonis was attached to the surface of the ova by means of pseudopod-like extensions that
Table 2. Piscirickettsia salmonis infecting Oncorhynchus mykiss. Detection of $P$. salmonis at spawning in smears of seminal fluids, coelomic fluids, and renal tissues of rainbow trout broodstock inoculated by intraperitoneal route, as tested by indirect immunofluorescence techniques (IFAT). IFAT interpretation: + , positive to the presence of $P$. salmonis, $>3$ bacteria; - , negative. All samples were analysed in duplicate, examining a total of 50 fields per smear at a magnification of $1000 \times$

\begin{tabular}{|c|c|c|c|c|}
\hline \multirow[t]{2}{*}{ No. } & \multicolumn{2}{|c|}{ Male } & \multicolumn{2}{|c|}{ Female } \\
\hline & Milt & Kidney & Coelomic fluid & Kidney \\
\hline 1 & + & + & + & + \\
\hline 2 & + & + & + & + \\
\hline 3 & + & - & + & - \\
\hline 4 & + & + & + & + \\
\hline 5 & - & + & + & + \\
\hline 6 & + & + & + & + \\
\hline 7 & + & - & + & + \\
\hline 8 & + & + & + & + \\
\hline Total & 7 & 6 & 7 & 6 \\
\hline$\%$ & 87.5 & 75 & 100 & 85.7 \\
\hline
\end{tabular}

Table 3. Piscirickettsia salmonis infecting Oncorhynchus mykiss. Presence of $P$. salmonis in alevins and $1 \mathrm{~g}$ fingerlings as tested by indirect immunofluorescence techniques (IFAT). Alevins were analysed by grinding and filtering of whole fish. Fingerlings correspond to testing of kidney smears. The $\mathrm{M}-\mathrm{F}$ - group of ova was obtained by experimental inoculation of $P$. salmonis during fertilisation. In total, $30 \mathrm{ml}$ of a suspension of $P$. salmonis with a titer of $10^{6.2} \mathrm{DICT} \mathrm{ml} \mathrm{m}^{-1}$ were added to a group of 600 ova

\begin{tabular}{|lccccc|}
\hline $\begin{array}{l}\text { Fish } \\
\text { type }\end{array}$ & $\begin{array}{c}\mathrm{M}-\mathrm{F}- \\
(\mathrm{n}=25)\end{array}$ & $\begin{array}{c}\mathrm{M}+\mathrm{F}- \\
(\mathrm{n}=25)\end{array}$ & $\begin{array}{c}\text { Group } \\
(\mathrm{n}=25)\end{array}$ & $\begin{array}{c}\mathrm{M}+\mathrm{F}+ \\
(\mathrm{n}=25)\end{array}$ & $\begin{array}{c}\mathrm{M}-\mathrm{F}-(+) \\
(\mathrm{n}=25)\end{array}$ \\
\hline $\begin{array}{l}\text { Alevin } \\
1 \text { g fingerling }\end{array}$ & 0 & $6(24 \%)$ & $4(16 \%)$ & $5(20 \%)$ & $7(28 \%)$ \\
& & & & & \\
\end{tabular}

apparently reached from the external membrane of the bacteria to the chorion of the ovum (Fig. 1). We have named these extensions 'piscirickettsial attachment complex' (PAC). These structures had a maximum length of $2.5 \mu \mathrm{m}$. Extensions were also observed to exist between microorganisms, forming a honeycomblike structure. These attachments were seen even during the last time period (60 min) (Fig. 2). At $1 \mathrm{~min}$, some $P$. salmonis cells were observed penetrating the interior of the ova through the chorion (Fig. 3). No PAC structures were observed in these microorganisms. After 5 min exposure, the bacteria without PAC could be visualised inside the ova (Fig. 4).

\section{DISCUSSION}

In the present study, vertical transmission to alevins 


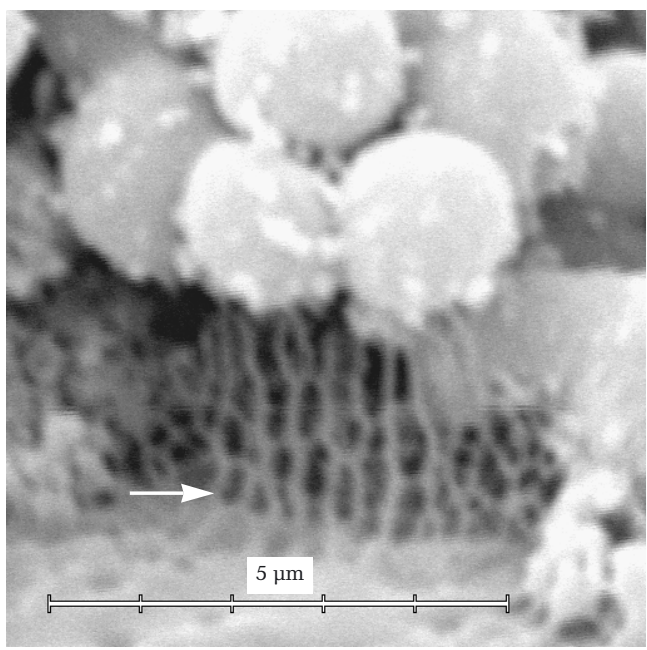

Fig. 1. Piscirickettsia salmonis infecting Oncorhynchus mykiss. $45 \mathrm{~s}$. Bacteria are observed attached to the surface of an ovum by means of cytoplasmic extensions ('piscirickettsial attachment complex'; PAC) (arrow). Note that the attachments also link the rickettsia themselves, forming a matrix. $17000 \times$

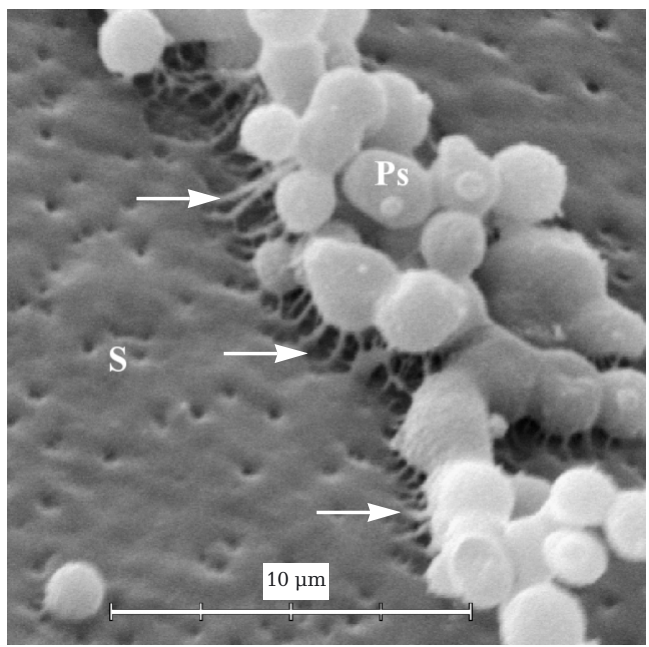

Fig. 2. Piscirickettsia salmonis infecting Oncorhynchus mykiss. 30 min. Bacterial cells (Ps) attached to the surface (S) of an ovum by means of the 'piscirickettsial attachment complex' (PAC; arrows). 6700x

was established through experimental infection of rainbow trout broodstock. Using scanning electron microscopy, it was observed that the bacterium attaches to the ova by means of extensions similar to multiple podosomes, which probably allowed it to adhere to and then penetrate the ovum during fertilisation.

In the present study, none of the broodstock presented signs or lesions of the disease, although a high concen-

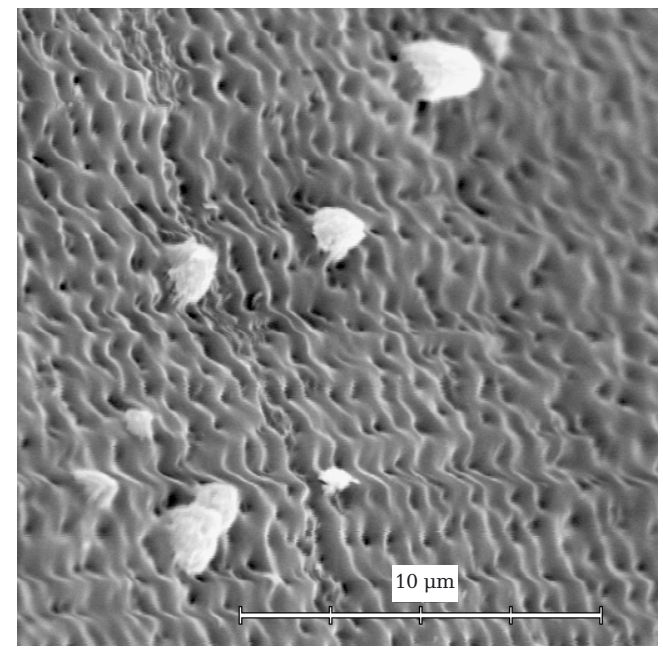

Fig. 3. Piscirickettsia salmonis infecting Oncorhynchus mykiss. 1 min. Bacterial cells attached to the chorion of the ovum. $6700 \times$

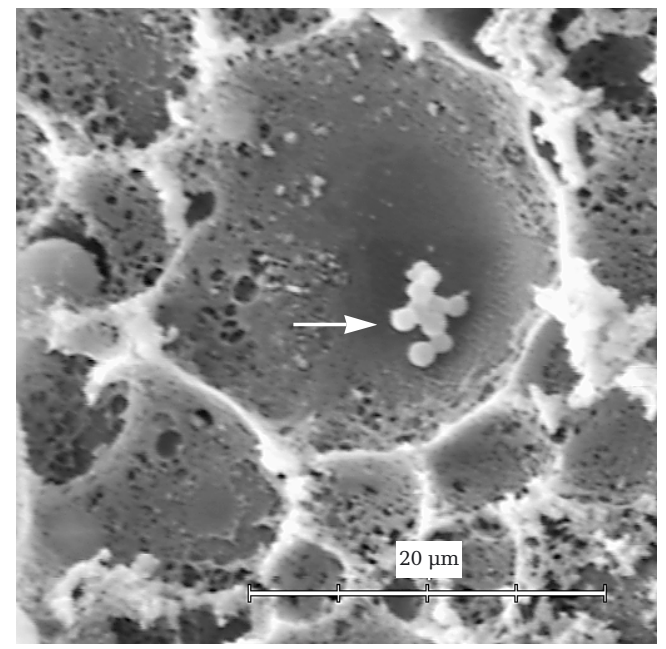

Fig. 4. Piscirickettsia salmonis infecting Oncorhynchus mykiss. 5 min. Bacterial cells (Ps; arrow) in the yolk sac of an ovum. No 'piscirickettsial attachment complex' (PAC) is observed. Ova + spermatocytes + Ps. $300 \times$

tration of bacteria was inoculated. This is consistent with previous observations (Larenas et al. 1996b) where male and female rainbow trout broodstock were inoculated. To date there is no record of clinical piscirickettsiosis in adult salmon under natural conditions, although individuals may test positive by kidney IFAT (Larenas et al. 1999). This leads to the supposition that although adult salmon (or broodstock) may be less susceptible to clinical disease, they may be asymptomatic carriers of the agent. 
In a previous experimental study, Larenas et al. (1996b) demonstrated Piscirickettsia salmonis infection of eyed-stage ova from male and/or female broodstock previously inoculated intraperitoneally with the agent. This suggested that infections in both male and females could result in infected progeny. In that study, the experiment was terminated prior to hatching or alevin development, so the viability of the infected progeny could not be determined.

Alternatively, studies carried out in naturally infected coho broodstock (Larenas et al. 1999) have confirmed the importance of the male in vertical transmission. In that study, Piscirickettsia salmonis was detected by means of IFAT in eyed-stage ova (6 to $20 \%$ ), alevin (6 to $13 \%$ ), and $1.2 \mathrm{~g}$ fingerlings (2 to $4 \%$ ). However, clinical disease was not observed and there was no difference in mortality compared to the negative control groups. These results support the hypothesis that fish, which are infected by the vertical route, become asymptomatic carriers of the disease. It is not known whether these fish will display signs of clinical disease upon a subsequent exposure to the agent, or whether they will be refractory to infection.

The fertilisation of gametes from non-inoculated broodstock in the presence of Piscirickettsia salmonis was carried out to establish the importance of ovarian and seminal fluids in the transmission of the disease. The presence of infected progeny at 2 different developmental stages (alevin and $1 \mathrm{~g}$ fingerling) shows that the bacteria in the suspension could enter the ova during fertilisation. In recent work at our lab (unpubl.), $P$. salmonis was demonstrated in coelomic and seminal fluids from rainbow trout and coho salmon broodstock belonging to a hatchery in the south of Chile. Furthermore, the progeny originating from the positive coho salmon broodstock were positive to the presence of the bacteria detected by IFAT and isolation in cell culture (CHSE-214). However, it is not possible to discard the possibility that infection occurred in the female prior to fertilisation.

In the present work, the presence of Piscirickettsia salmonis in progeny of non-inoculated females and positive males indicates that milt was a contributing factor to infection as Piscirickettsia salmonis was detected in seminal fluid from 7 out of 8 males used at spawning, supporting the hypothesis that this is an important route of transmission.

Examination of ova incubated with Piscirickettsia salmonis by scanning electron microscopy shows that the bacteria can adhere to the ovum by means of extensions that probably originate from the external membrane of the bacteria. These extensions, which we have termed the 'piscirickettsial attachment complex' (PAC), attach quickly to the chorion of the ovum. These extensions also link the bacteria themselves. This phe- nomenon was observed as early as $45 \mathrm{~s}$ after exposure time. Lannan \& Fryer (1994) have shown in vitro that the agent survives only a few seconds in freshwater; thus, when natural fertilisation occurs in freshwater, the agent must have a strategy that will allow its rapid entry into susceptible ova, which would offer it a protected and adequate environment for survival. The present results serve to corroborate this idea, as bacteria were observed within ova as early as 5 min postinfection.

The presence of extensions or podosomes has not been described previously, nor are there records of any similar investigation having been carried out previously for other microorganisms. Smith et al. (1999) established that Piscirickettsia salmonis can penetrate intact skin and gills of rainbow trout. It is possible that the mechanism described in this study may be the mode of entry through intact epithelia of salmonid fish during both natural and experimental infections.

Evelyn et al. (1986) infected ova by immersing them in ovarian fluid containing high concentrations of Renibacterium salmoninarum, suggesting that transmission may occur during ovulation, when ova come in contact with contaminated ovarian fluid. Infection of ova apparently occurs through the micropyle (Bruno \& Munro 1986). This mode of infection would be favoured when the numbers of bacteria in the fluid are high. There is also evidence that infection may take place during oogenesis (Lee \& Evelyn 1989). As there is currently no evidence that males transmit $R$. salmoninarum through milt, control strategies are limited to females (Fryer \& Lannan 1993).

Yousif et al. (1994) reported that susceptibility to egg lysozyme affects the capacity of bacteria to survive with the ova. Thus, Renibacterium salmoninarum (Yousif et al. 1994) and Flavobacterium psychrophilum (Kumagai et al. 2000) are resistant to the enzyme. Although Piscirickettsia salmonis was transmitted vertically in the present study, the mechanisms which allow for its survival within the ovum are unknown.

The results support the hypothesis of vertical transmission for Piscirickettsia salmonis and also demonstrate that broodstock tested negative by IFAT examination of renal tissue smears, which proved to be positive when their reproductive fluids were analysed. Therefore to control piscirickettsiosis, diagnosis should be carried out from samples of seminal and ovarian fluids as well as renal tissue to ensure the negative status of broodstock.

In conclusion, the present study suggests vertical transmission of Piscirickettsia salmonis, as well as the importance of the male in this process. The capacity of $P$. salmonis to adhere to ova, allowing its entry, was also demonstrated, suggesting a possible mechanism for vertical transmission. 
Acknowledgements. We thank Drs. E. Arellano and A. Guajardo for their help with the experimental trials, and Drs. J. Arias and C. Rose for valuable contributions to this paper. This work was supported by Grant 1000788 of the Chilean Fund for Science and Technology (FONDECYT).

\section{LITERATURE CITED}

Bruno DW, Munro ALS (1986) Observations on Renibacterium salmoninarum and the salmonid egg. Dis Aquat Org 1:83-87

Cvitanich J, Gárate O, Smith CE (1991) The isolation of a rickettsia-like organism causing disease and mortality in Chilean salmonids and its confirmation by Koch's postulate. J Fish Dis 14:121-145

Evelyn TPT, Prosperi-Porta L, Ketcheson JE (1986) Experimental intra-ovum infection of salmonid eggs with Renibacterium salmoninarum and vertical transmission of the pathogen with such eggs despite their treatment with erythromycin. Dis Aquat Org 1:197-202

Fryer JL, Lannan CN (1993) The history and current status of Renibacterium salmoninarum, the causative agent of bacterial kidney disease in Pacific salmon. Fish Res 17: $15-33$

Fryer JL, Lannan C, Garcés L, Larenas J, Smith P (1990) Isolation of a rickettsiales-like organism from diseased coho salmon (Oncorhynchus kisutch) in Chile. Fish Pathol 25: 107-114

Fryer JL, Lannan CN, Giovannoni SJ, Wood ND (1992) Piscirickettsia salmonis gen. nov., sp. nov., the causative agent of an epizootic disease in salmonid fishes. Int J Syst Bacteriol 42:120-126

Grant AN, Brown AG, Cox DJ, Birkbeck TH, Griffen AA (1996) Rickettsia-like organism in farmed salmon. Vet Rec 138:423-424

Jones SRM, Markham RJF, Groman DB, Cusack RR (1998) Virulence and antigenic characteristics of a cultured Rickettsiales-like organism isolated from farmed Atlantic salmon Salmo salar in eastern Canada. Dis Aquat Org 33: 25-31

Kumagai A, Yamaoka Sh, Takahashi K, Fukuda H, Wakabayashi H (2000) Waterborne transmission of Flavobac-

Editorial responsibility: David Bruno,

Aberdeen, Scotland, UK terium psychrophilum in coho salmon eggs. Fish Pathol 35:25-28

Lannan C, Fryer J (1994) Extracellular survival of Piscirickettsia salmonis. J Fish Dis 17:545-548

Lannan CN, Winton JR, Fryer JL (1984) Fish cell lines: establishment and characterization of nine cell lines from salmonids. In Vitro 20:671-676

Lannan C, Ewing SA, Fryer JL (1991) A fluorescent antibody test for detection of rickettsia causing disease in Chilean salmonids. J Aquat Anim Health 3:229-234

Larenas J, Astorga C, Contreras J, Garcés H, Fryer J, Smith P (1996a) Rapid detection of Piscirickettsia salmonis using microwave irradiation. Fish Pathol 31:231-232

Larenas J, Astorga C, Contreras J, Smith P (1996b) Detección de Piscirickettsia salmonis en ovas fertilizadas provenientes de truchas arco iris (Oncorhynchus mykiss) experimentalmente infectadas. Arch Med Vet 28:161-166

Larenas J, Pérez B, Hidalgo L, Contreras J, Smith PA (1999) Vertical transmission of Piscirickettsia salmonis in coho salmon (Oncorhynchus kisutch) under farming conditions. IXth International Conference 'Diseases of Fish and Shellfish', Abstracts Book p-069, Rhodes

Lee EG, Evelyn TP (1989) Effect of Renibacterium salmoninarum levels in the ovarian fluid of spawning chinook on the prevalence of the pathogen in their eggs and progeny. Dis Aquat Org 7:179-184

Olsen AB, Melby HP, Speilberg L, Evensen $\varnothing$, Hastein T (1997) Piscirickettsia salmonis infection in Atlantic salmon Salmo salar in Norway-epidemiological, pathological and microbiological findings. Dis Aquat Org 31:35-48

Palmer R, Ruttledge M, Callanan K, Drinan E (1997) A piscirickettsiosis-like disease in farmed Atlantic salmon in Ireland-isolation of the agent. Bull Eur Assoc Fish Pathol $17: 68-72$

Reed LJ, Muench H (1938) A simple method of estimating fifty percent endpoints. Am J Hyg 27:497-499

Smith PA, Pizarro P, Ojeda P, Contreras J, Oyanedel S, Larenas J (1999) Routes of entry of Piscirickettsia salmonis in rainbow trout Oncorhynchus mykiss. Dis Aquat Org 37: $165-172$

Yousif AN, Albright LJ, Evelyn TPT (1994) In vitro evidence for the antibacterial role of lysozyme in salmonid eggs. Dis Aquat Org 19:15-19

Submitted: January 23, 2002; Accepted: April 23, 2003

Proofs received from author(s): August 7, 2003 